\title{
Juridic Review On-Line Approval Of The Deed Of Establishment Of A Limited Company Through Sisminbakum
}

\section{Emmy Butar Butar}

North Sumatera University Faculty Of Law. E-mail: emmybutar@gmail.com

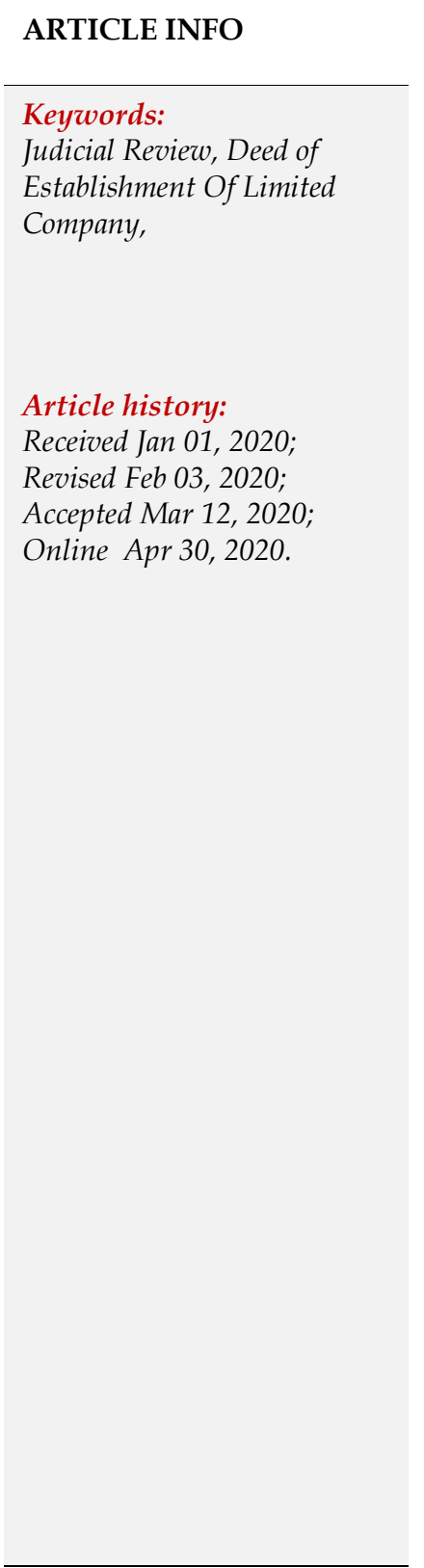

\begin{abstract}
Limited Liability Company (PT) is a form of legal entity in Indonesia. A company obtains the status of a legal entity after the deed of establishment is approved by the Minister of Law and Human Rights. To obtain the legalization of a legal entity, a notary as the power of attorney submits an application for legalization of the establishment of a PT through information technology services for the Legal Entity Administration System (Sisminbakum) electronically to the Minister of Law and Human Rights by filling out the Model I Form. The online legal entity legalization service through Sisminbakum is an issue new in Law no. 40 of 2007 concerning Limited Liability Companies, but in reality the Sisminbakum has been in force since 2001, while UUPT No 1 of 1995 does not regulate the process of ratifying the deed of establishment of a PT whether it is done manually or electronically. The problem in this thesis is regarding the procedure for establishing a PT based on UUPT No 40 of 2007, the legal basis for the ratification of the deed of establishment of a PT online through Sisminbakum, the procedure for ratifying the deed of establishment of a PT online and the legal certainty of the SK legalization of the legal entity PT which is signed electronically. The writing of this thesis uses a descriptive normative legal method. Secondary data were collected through library research, then analyzed using deductive and inductive methods. Sisminbakum is an official website which is a computerized system in ratifying the establishment of a legal entity owned by the Directorate General of General Legal Administration (Dirjen AHU). The Sisminbakum is enforced based on the Decree of the Minister of Justice and Human Rights of the Republic of Indonesia No. M-01.HT.01.01. Year 2000 concerning the Enforcement of the Legal Entity Administration System at the Directorate General of General Legal Administration, Ministry of Law and Human Rights of the Republic of Indonesia. The application for legalization of the company's deed of establishment is submitted by a notary through the Sisminbakum by filling out the Model I Form I (FIAN I). The steps that must be taken in the FIAN I application through this Sisminbakum are: checking the name, then filling out the Pre FIAN I Supporting Documents (FIAN I Prerequisites) then filling in the data in the FIAN I process then correcting and ending the sending of Physical Documents. If the physical documents are complete and meet the requirements, an electronic decision letter will be signed by the Minister of Law and Human Rights and then sent to the requesting notary. The decision letter for ratification of this PT has strong legal force.
\end{abstract}

This is an open access article under the CC BY-NC license. 


\section{Introduction}

The general target of Indonesia's development is directed at increasing the prosperity of the people who are more evenly distributed. To realize the welfare of the community, it is hoped that Limited Liability Companies (PT) can become one of the pillars of national economic development, because Limited Liability Companies are important business entities and are widely available in the world, including Indonesia. The presence of PT as a business vehicle contributes to almost all areas of human life. The Limited Liability Company has created jobs, improved the welfare of the community and made significant contributions to economic and social development.

Limited Liability Company is one of the relatively dominant business entities in Indonesia's economic activities, because it has characteristics and characteristics and features that are not owned by other forms of business entities, namely:

a. is a form of partnership that is a legal entity

b. is a collection of capital or shares

c. has a wealth that is separate from the wealth of its shareholders

d. shareholders have limited liability

e. there is a separation of functions between shareholders and management or directors

f. have a commissioner who functions as a supervisor

g. the highest authority is at the General Meeting of Shareholders (GMS).

Limited Liability Companies are dominantly used by business actors to develop their business, because PT has several advantages that make it so attractive. In Indonesia itself the form of Limited Liability Company is more widely used or preferred. There are several reasons why the form of Limited Liability Company is preferred, among others, because the Limited Liability Company as a business entity with legal entity status has limited liability for its owners or shareholders, then the shareholders do not have to concentrate on managing one particular company, but simply submit the management. day-to-day operations to professional managers, while shareholders or shareholders may take up positions as Commissioners or on the Board of Commissioners of the company concerned.

Whereas in addition, by taking the form of a Limited Liability Company which has its own assets (separately), then the management, capital owners, or shareholders and the directors and commissioners of the company will feel safe, where their personal assets will not be contested in connection with their actions. on behalf of the Limited Liability Company concerned, as long as and all the management of the Limited Liability Company running the helm of the company are still within the limits permitted by applicable law.

Limited Liability Company as an economic organization has a greater ability to develop itself because: First, it has the ability to raise more funds than other forms of business without disturbing its existence. Second, have the ability to develop themselves without affecting their existence. Third, it can be designed to anticipate long-term business with a large scale, both local, national and international. Fourth, PT is able to cooperate between companies while maintaining its identity, including anyone who supports it (meaning shareholders).

This opinion is based on the fact that a Limited Liability Company has the ability to develop itself and has the potential to provide benefits for its own agency as well as for shareholders. We can see this in the reality that exists in our midst, the economic organization (business entity) owned by a conglomerate that controls several economic sectors in the form of a Limited Liability Company. At first as a mediocre (small) company, it gradually developed into a giant company, it has the ability to develop itself to provide benefits for the institution and its shareholders. 
It is affirmed in Article 1 paragraph (1) of Law Number 40 of 2007 concerning Limited Liability Companies that a Limited Liability Company is a legal entity established based on an agreement. PT as a civil legal entity that has the status of independence (persona standi in judicio) of course has its own legal identity and is separate from the legal identity of its shareholders, directors and other organs.

A company obtains the status of a legal entity after the deed of establishment is approved by the Minister of Law and Human Rights, as stipulated in Article 7 paragraph (4) of the Company Law. So if a company has not been legalized, then the company is not yet a legal entity.

In order for the company to be officially recognized as a legal entity, the deed of establishment in the form of a notarial deed must be submitted jointly by the founders through an application to obtain a decision of the Minister (Minister of Law and Human Rights) regarding the legalization of a legal entity. To obtain a Ministerial Decree regarding the ratification of the deed of establishment or legalization of a legal entity as referred to in Article 7 paragraph (4) of the Company Law, a notary as the proxy of the founder submits an application for the legalization of the establishment of a PT through electronic information technology services for the legal entity administration system to the Minister of Law and Human Rights. by filling in the model I form.

In Law no. 40 of 2007 concerning Limited Liability Companies, hereinafter referred to as UUPT, there are additional new issues, including the adoption of the principles of social and environmental responsibility or corporate social responsibility, hereinafter referred to as (CSR). In addition, the Company Law also recognizes the principles of Islamic economics which have developed rapidly in recent years. Article 109 of the Company Law recognizes sharia economic principles by requiring the existence of a Sharia Supervisory Board in companies that run Sharia-based businesses. And besides that, the Company Law also regulates the buy back of shares by buy back companies. In addition, there is also a prohibition on cross-holding (Article 36 UUPT), and the issue of business judgment rule (Article 135 UUPT). With regard to the process of establishing a PT or submitting an application and granting legalization of legal entity status, The UUPT has fulfilled the demands of the community to obtain fast services which are carried out through the electronic information technology service of Sisminbakum. This issue is a service for establishing a Limited Liability Company legal entity which is carried out electronically.

\section{Method}

In the preparation of this thesis, a descriptive normative legal research method was used. Normative legal research is research by only processing and using secondary data. While the descriptive nature means that the research is sometimes carried out by conducting a survey in the field to obtain information that can support existing theories. Data Analysis Secondary data that has been systematically compiled and then analyzed in a perspective using deductive and inductive methods. The deductive method is done by reading, interpreting and comparing. While the inductive method is carried out by translating various sources related to the topic in this thesis, so that conclusions are obtained in accordance with the research that has been formulated.

3. Analysis and Results.

3.1 Online Flow Of Establishment Of Pt Establishment Through Sisminbakum And Legal Assurance Sk Pt That Is Electronically Signed As Evidence Tool 


\section{a. Flow Of Legalization of PT Estabilishment Deed Online Through Sisminbakum}

In the manual system or the old system, all work is done manually, starting from receiving files from the notary which includes checking completeness and names, payments and making control cards. The documents in this manual process are all still in the form of report papers, including the establishment, approval and report.

Furthermore, the corrector who is in charge of checking the completeness of these documents which is a letter of application for approval of the company along with the completeness of other documents submitted by the founders or their proxies in this case is a notary. Furthermore, these documents will be re-examined by the Head of the technical section (Kasi), and the Head of the Sub-Directorate (Kasubdit) of legal entities which will later be clarified again by the Director of Civil Affairs, followed by printing of the Decree which will be signed by the Directorate General, lastly a notary will take the Company's Decree and The notarial deed will be documented in the Administration section.99

To overcome this very long process, by utilizing increasingly developing technology, an online system is created that can be accessed by Notaries throughout Indonesia, namely through Sisminbakum.

Through Sisminbakum the entire manufacturing process is carried out online which can be accessed by notaries who follow the sisminbakum from all over Indonesia. Each notary registered with Sisminbakum will be given a User ID and Password for security during processing. Notaries can carry out direct supervision through the internet network 24 hours so that they can find out the progress of processing and if there are errors can be corrected directly as well as communication between the Director General of AHU and the notary via e-mail.

The application for ratification of the company's legal entity is carried out by a notary as the proxy of the founder. An application to obtain a Ministerial Decree regarding the legalization of a legal entity must be submitted to the Minister no later than 60 (sixty) days from the date the deed is signed. In the event that the application to obtain a Ministerial Decree is not submitted within 60 (sixty) days from the date the deed of establishment is signed, the deed of establishment is void after the expiration of that period and the company which has not obtained the status of a legal entity is dissolved by law and the settlement is carried out by the founder.

The application for legalization of the company's deed of establishment is submitted by a notary through the Sisminbakum by filling out the Model I Form I (FIAN I). Fian model I is a format for filling out a notary deed that functions in the case of the establishment of a Limited Liability Company to obtain approval from the Minister of Law and Human Rights where the notary must fill in, among others:

1) The name of the company and the position of the company

2) Period of establishment of the Limited Liability Company

3) The purpose and objectives of the Company's business activities

4) The amount of authorized capital, issued capital, and paid-up capital

5) Full address of the company.

The steps that must be taken in submitting the company name are first selecting the name check menu then selecting the company name submission after that enter the company name for which the process will be submitted. To apply for a company name, you must first have paid Non-Tax State Revenue (PNBP) by filling in the date of PNBP payment in the column provided. After the data has been entered, the next step is to move on to the next process, namely: Pre Fian I. 
The steps that must be taken in applying for FIAN I through the Sisminbakum must go through several stages, namely:

1) Name check

To start making a transaction through Sisminbakum, whether it be establishment, change or reporting, the notary must fill in the user id and password of the notary concerned in the $\log$ in menu. The log in menu is the first step to enter the menus intended for notaries. While the log out menu is a menu provided for notaries when they are about to finish or will leave the Sisminbakum transaction process for the security of the data that has been filled in so that it cannot be seen or changed by unwanted people. After logging in to the Sisminbakum application, the first thing to do is check the name of the company to be registered. In accordance with the Government Regulation of the Republic of Indonesia Number 26 of 1998 concerning the Use of the Name of a Limited Liability Company which is basically made to regulate the procedure for submitting an application for approval of the use of a company name as well as guidelines for refusing an application for approval of the use of a company name, every use of the name of a company must obtain the approval of the Minister of Law. and human rights of the Republic of Indonesia.

2) Filling out Pre FIAN I Supporting Documents (FIAN I Prerequisites)

Pre Fian I is a follow-up process that must be passed after submitting the name of the company and before the Fian I stage. At this stage, you are required to put a "Yes" mark on the documents that must be submitted when submitting physical documents.

After completing the Pre-Fian I stage, it then enters the Fian I process which is the last stage for filling in company data. If the data entered are in accordance with the Director General of AHU, then all you have to do is enter the physical documents or send the company's physical documents to the Ministry of Law and Human Rights of the Republic of Indonesia and just waiting for the clarification process of the data that has been entered with physical documents.

3) Fill in the data in the Fian I process

At the time of entering Fian I, namely filling in the basic data, an access fee of Rp. 1000.000,(one million rupiah) and 10\% VAT. The main data that must be filled in on this Fian I page are as follows:

a) The main data, namely:

Company Address, No. NPWP, Time period by specifying limited or unlimited and Term of Year, if the term is limited

b) Company Deed, the data that must be filled are:

The domicile of the Company which will be printed on the Decree. Deed establishment, the Notary must fill in No. the deed, the date of the deed, while the name of the notary of establishment, the substitute notary and the maker of the deed can be ignored if the maker of the deed and the submitter of the deed are the same notary. The name of the founding notary is filled in if the deed maker is not a notary logged in but a deed of amendment must be made. The name of the substitute notary, to be filled in if the maker of the deed is a substitute notary. Amendment deed. If the deed submitted is only one deed, then this amendment deed can be left blank, if there are two deeds, the last deed is filled in. Repair deed. To be filled in if there is a correction or need for improvement that comes from the Department of Law and Human Rights. Submission of deed, namely who submits the deed, namely notary log in or notary substitute. Decree of the stipulation of a substitute Notary, if in one of the deeds above there is a deed maker or the sender of the deed is a substitute notary.

c) Capital and Shares, the data that must be filled in are data that are in accordance with the amount of capital specified in the articles of association, namely: The authorized capital of the Company, at least Rp. 50,000,000,- (fifty million rupiah), Issued capital is the issued capital of the shareholders of the Company, the minimum amount is $25 \%$ of the authorized capital, Paid-up capital is the amount of fully paid-up capital by the shareholders of the company, a minimum amount of $25 \%$ of the authorized capital. The paid-up amount has the same value as the paid-up capital, the total number of shares is 
the total number of shares owned by the shareholders of the company, the number of shares issued is the number of shares that have been issued by the shareholders, The par value of shares is the price or value of a share.

d) Company Establishment

e) After completing the Fian I stage, the process of ratifying the Company is continued in the monitoring process. In the monitoring process, all transaction processes that have been carried out since the Company's order until the Decision Letter (SK) process can be known.

4) Correction

In the process of entering data into the Sisminbakum database or data bank, an error may occur because it is not in accordance with the provisions or laws and regulations. Several stages of inspection will be carried out by the Director General of AHU to approve or accept transactions that have been made. To find out whether there are corrections or errors made in data input can be seen on the monitoring menu. If the data that has been entered is corrected or something needs to be corrected, it can be seen in detail the error through the monitoring menu. If the data entered is accepted, then on the monitoring page there is a date and time on the status of Fian not objecting to the Minister and he is required to submit the physical documents of the Company no later than 30 (thirty) days from the date and time that the Minister does not object. Correction occurs if on the monitoring page at the stage of checking the corrector, clarification of the Head of Section (head of section) and the Head of Sub-Directorate, there is a date and time accompanied by a corrected sentence or the application is rejected accompanied by a description of the error that must be corrected.

5) Physical Document Delivery

The physical document delivery stage is the last process that must be fulfilled to complete the entire series of legalization processes for the company's legal entity from ordering names, Pra Fian, filling in Fian to submitting physical documents.

b. Legal Certainty Decision letter ratifying PT which is signed electronically as evidence

Regarding evidence recognized in civil proceedings, it is regulated enumeratively in Article 1866 of the Civil Code, Article 164 HIR, which consists of :

1) written proof

2) evidence with witnesses

3) guess

4) confession

5) oath

Evidence submitted outside of what is stipulated by law: is not valid as evidence, therefore it has no evidentiary value to strengthen the truth of the arguments or rebuttals put forward. One of the important conditions for the writing to be used as evidence is that it must be signed by the parties involved in its creation. A letter or writing that contains a clear and clear statement or agreement, but is not signed in terms of the law of proof, is not perfect as a letter or or deed so that it is not valid to be used as written evidence. The function of the signature (hand signing, signature) in a letter is none other than ensuring identification or determining the correctness of the signer's characteristics. And at the same time the signer guarantees the truth of the contents contained in the writing.

The legislation that so far guarantees the validity or legal certainty of this Limited Liability Company Decree is Law Number 8 of 1997 concerning Company Documents (UUDP). Article 1 number (2) of the UUDP states that company documents are data or records and or information made and or received in the context of carrying out their activities, either written on paper or other means or recorded in any form that can be seen, read, or heard. In the article it is known that the company's documents are not only data, records, or information received by the company concerned. 
Furthermore, Article 12 paragraph (1) of the UUDP stipulates that company documents can be transferred to microfilm or other media. Meanwhile, article 15 paragraph (1) of the UUDP stipulates that company documents that have been published in micro-film or other media as referred to in article 12 paragraph (1) and or the printout thereof shall constitute valid evidence.

So documents from a company (including deed of establishment) produced using electronic means are legal evidence. Article 15 paragraph (1) of the UUDP is in accordance with Article 5 paragraph (2) of the ITE Law which states that electronic information and/or electronic documents and/or their printed results are an extension of legal evidence in accordance with procedural law in force in Indonesia.

\section{Conclusion}

The implementation of Micro, Small and Medium Business Loans at Bank BPD Aceh is initiated by filling out the credit application form, namely to facilitate the Bank in obtaining the required data, then the Bank uses a credit application form that must be filled in by the customer, after (1) To establish a company, it is necessary to fulfill the conditions and procedures that have been determined by the Company Law. The procedure for establishing a PT is, (2) Making the Deed of Establishment of a Limited Liability Company, (3) endorsement, (4) Registration, (5) Limited Liability Company Announcement.

Since 2001, the legalization of the deed of establishment of PT has been carried out through information technology services for the legal entity administration system (SISMINBAKUM). Sisminbakum which was enforced based on the Decree of the Minister of Justice and Human Rights of the Republic of Indonesia No. M-01.HT.01.01. Year 2000 concerning the Enforcement of the Legal Entity Administration System at the Directorate General of General Legal Administration, Ministry of Justice and Human Rights of the Republic of Indonesia, has been strengthened by Law Number 40 of 2007 concerning Limited Liability Companies as the legal basis so that in the process of establishing a PT there are no deviations. Meanwhile, the technical guidelines for the implementation of the Sisminbakum are further regulated in the Regulation of the Minister of Law and Human Rights of the Republic of Indonesia Number M01.HT.01.

Sisminbakum is a Legal Entity Administration System using an online system through the internet network in terms of the settlement of legal entities including requests for legalization of the deed of establishment of PT (Fian I), and applications for approval (Fian 2), as well as submission of reports on the deed of amendment to the articles of association of PT (Fian 3).

The ratification of the deed of establishment through the sisminbakum provides considerable benefits to the Director General of AHU as well as to the notary. As for the advantages of the sisminbakum, namely the improvement of services to the community to be more effective and efficient, accurate, fast and transparent. Meanwhile, a common obstacle that is often experienced by users of this system is the length of loading.

The application for legalization of the company's deed of establishment is submitted by a notary through the Sisminbakum by filling out the Model I Form I (FIAN I). Fian model I is a format for filling out a notary deed that functions in the case of the establishment of a Limited Liability Company to obtain approval from the Minister of Law and Human Rights. The steps that must be taken in the application for FIAN I through the Sisminbakum are: (1) Name check, (2) Filling out Pre FIAN I Supporting Documents (FIAN I Prerequisites), (3) Fill in the data in the Fian I . process, (4) Correction, (5) Physical Document Delivery.

Physical documents are sent after a statement of no objection from the Minister of Law and Human Rights. If the physical documents are complete and meet the requirements, an 
electronic decision letter will be signed by the Minister of Law and Human Rights and then sent to the requesting notary.

The decision letter on the legalization of the PT which is signed electronically in determining the legality of the establishment of the PT has strong legal force. Electronic signatures have a valid legal force, the same as conventional signatures that use wet ink and stamped.

\section{References}

Ali, Chidir, Legal Entity, Bandung: Alumni, 1991.

Adjie, Habib, Legal Entity Status, Principles and Social Responsibility of Limited Liability Companies, Bandung: Mandar Maju, 2008.

Budiarto, Agus, Company Law Series Legal Position and Responsibilities of Founder of Limited Liability Company, Jakarta: Ghalia Indonesia, 2002.

Harahap, M. Yahya, Civil Procedure Law, Jakarta: Sinar Graphic, 2006 Muhammad, Abdulkaadir, Introduction to Indonesian Corporate Law, Bandung:

Image of Aditya Bakti, 1999.

Murjiyanto, R, Introduction to Commercial Law Aspects of Corporate Law and Prohibition of Monopolistic Practices, Yogyakarta: Liberty in collaboration with the Publishing Agency of the Faculty of Law, University of Janabadra, 2002.

Purwosutjipto, HMN, Basic Understanding of Indonesian Commercial Law, Jakarta: Djambatan, 1999.

Prasetya, Rudhi, Independent Limited Liability Company, Bandung: PT Citra Aditya bakti, 1996.

Rido, Ali, Legal Entity and Legal Entity Position Company, Association, Cooperative, Foundation, Waqf, Bandung: PT Alumni, 1983.

Rusli, Hardijan, Legal Entities and Forms of Companies in Indonesia, Jakarta: Huperindo, 1989.

Soekardono, Indonesian Commercial Law, Jakarta: Rajawali Pers, 1983.

Sembiring, Sentosa, Company Law on Limited Liability Companies, Bandung, Nuansa Aulia, 2006

Surya, Indra, Yustiavanda, Ivan, Implementation of GCG, Jakarta: Kencana and the Capital Market and Financial Research Institute, FH UI, 2006

Usman,Racmadi, Legal Dimensions of Limited Liability Companies, Bandung: Alumni, 2004.

Widjaya, IG Ray, Limited Liability Company Law, Jakarta: Megapoin Division of Ksaint Blanc, 2003.

Wahyono, Teguh, Computer Ethics and Professional Responsibility in the field of Information Technology, Yogyakarta: Andi Publisher, 2006.

Yani, Ahmad \& Gunawan Widjaya, Limited Liability Company Business Law Series, Jakarta: Rajawali Pers, 1999.

Republic of Indonesia, Law no. 40 of 2007 concerning Limited Liability Companies.

Republic of Indonesia, Law no. 11 of 2008 concerning the Internet and Electronic Transactions.

Republic of Indonesia, Law no. 8 of 1998 concerning Company Documents of the Republic of Indonesia. 
Government Regulation of the Republic of Indonesia Number 26 of 1998 concerning the Use of Limited Liability Company Names

The Republic of Indonesia, Regulation of the Minister of Law and Human Rights Number M-01.HT.01.10 of 2007 concerning Procedures for Submitting Applications for Legal Entities and Approval of Amendments to the Articles of Association, Submission of Notification of Amendments to the Articles of Association and Changes in Company Data.

Republic of Indonesia, Regulation of the Minister of Law and Human Rights No. M-02. HT.01.10 of 2007 concerning Procedures for Announcement of PT in TBNRI.

Minister of Law and Human Rights Regulation No. M-01HT.01.01 of 2008 concerning Company Register

Republic of Indonesia, Decree of the Minister of Justice and Human Rights No. M-01.HT.01.01 Year 2001.

Republic of Indonesia, Ministerial Decree and Human Rights No. : M-01.HT.01.01. Year 2000 concerning the Enforcement of the Legal Entity Administration System at the Directorate General of General Legal Administration, Ministry of Justice and Human Rights of the Republic of Indonesia.

Circular of Dirjrn AHU No: C-UM.06.10-05 Regarding Technical Instructions for the Implementation of Sisminbakum.

Yeriza, Sylvi, Legal Aspects of Settlement of Limited Liability Company Legal Entities through Sisminbakum, Postgraduate Legal Studies Thesis, University of North Sumatra, Medan, 2005.

Marianne Magda, thesis, Validity of Electronic Signatures in the Process of Establishing a PT Based on Law no. 40 of 2007, Thesis of Postgraduate Law, University of North Sumatra, Medan, 2007.

Tumbuan, B. G Fred, Duties and Authorities of Limited Liability Company Organs according to the Limited Liability Company Law, (delivered in the socialization of the Law of the Republic of Indonesia Number 40 of 2007 concerning Limited Liability Companies, 2007.

Agung Mattauch, Ibn Nazar, What is the Sisminbakum Project? Court Magazine, issue V, 01-15 February 2009.

News, http:/ /www.sisminbakum.go.id , accessed on March 4, 2009.

Budi supriadi, Mechanism endorsement Company, http://www.google.com, accessed on March 4, 2009.

How the old system works http://www.sisminbakum.go.id, accessed on March 4, 2009.

Irma Devita Purnamasari, Establishment of a Limited Liability Company (www.goegle.com), accessed on 22 January 2008.

Why SABH, http:/ / www.sisminbakum.go.id, accessed on March 4, 2009.

Yusril Ihza Mahendra's explanation about the sisminbakum, http://www.google.com, accessed on March 4, 2009.

Often overwhelmed, http://www.sisminbakum.go.id, accessed on March 4, 2009.

sisminbakum,http://www.sisminbakum.go.id, accessed on March 4, 2009.

Misguided, http://www.google.com , accessed on March 4, 2009. 